\title{
No estúdio fotográfico de Fidanza: a construção da imagem das mulheres escravizadas na cidade de Belém (1869-1875)
}

In Fidanza's photographic studio: the construction of the image of enslaved women in the Belém city (1869-1875)

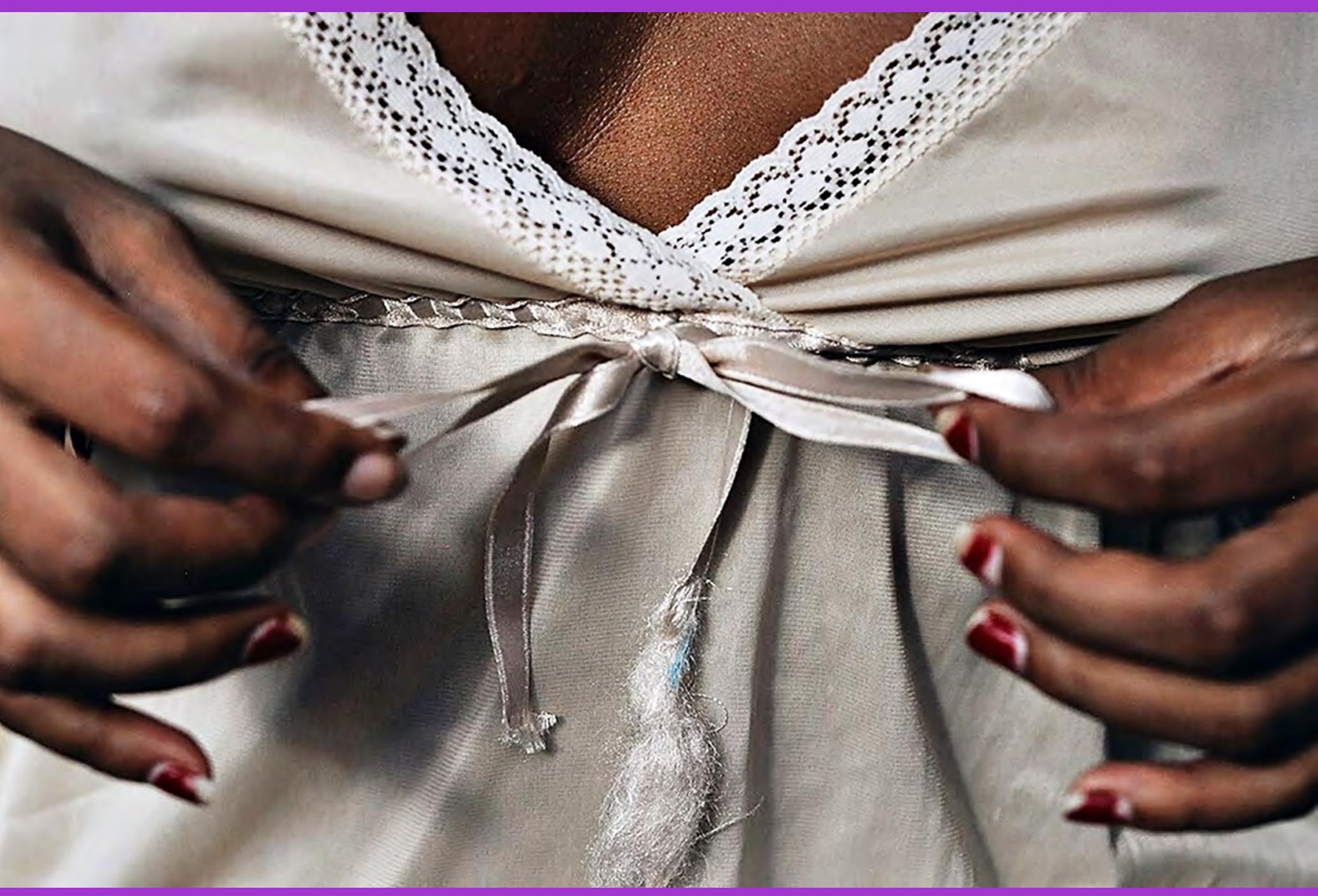




\section{Amanda Gatinho Teixeira ${ }^{1}$}

ORCID: https://orcid.org/0000-0003-4598-443X

[resumo] 0 presente artigo procura analisar parte da obra do fotógrafo português Felipe Augusto Fidanza, que começou a trabalhar em Belém no ano de 1867, tornando-se uma das principais referências no campo da fotografia da região Norte brasileira. Sua obra compõe um importante acervo documental da virada do século XX, em que foram retratados cenas urbanas do cotidiano da cidade e "tipos" sociais que circulavam pelas ruas. A partir da análise de cinco fotografias de diferentes mulheres, observamos seus vestuários e adornos corporais, bem como suas expressões e posturas que nos concedem importantes pistas que ajudam a revelar suas identidades e parte de suas respectivas histórias.

[palavras-chave] Felipe Augusto Fidanza. Mulheres escravizadas. Fotografia. Vestuário. Adornos.

[abstract] This paper aims to analyze part of the work of the portuguese photographer Felipe Augusto Fidanza, who started photographing in Belém city in 1867, becoming one of the main references in the field of photography in the north Brazilian region. His work is part of an important documentary collection from the turn of the 20th century, in which urban scenes of everyday life in the city and the social "types" that circulated on the streets were portrayed. From the analysis of five photographs of different women, we observe their clothing and body adornments, as well as, their expressions and postures that grant us important clues that help to reveal their identities and part of their respective stories.

[keywords] Felipe Augusto Fidanza. Enslaved women. Photography. Clothes. Ornaments.

Recebido em: 13-03-2020

Aprovado em: 11-05-2020

\footnotetext{
1 Mestre em Antropologia (UFPA).

E-mail: agteixeira10@gmail.com. Lattes: http://Lattes.cnpq.br/0991487149859516.
} 


\section{Primeiras palavras}

No presente artigo, foram analisadas cinco fotografias de Felipe Fidanza, do período de 1869 a 1875, pertencentes à coleção Alphons Stübell, as quais seguem o formato cartão de visita $(5,5 \times 9,2 \mathrm{~cm})$, que, por causa do seu preço modesto, permitiu que pessoas de diferentes níveis sociais tivessem acesso à novidade. Tal formato popularizou o retrato de corpo inteiro e, com ele, o espaço vazio em volta do modelo, que passou a ser utilizado como cenário, assim como também ocorria na pintura.

Do ponto de vista metodológico, ao incluirmos as fotografias como fontes da pesquisa histórica, Carvalho e Lima (2017) sugerem o trabalho com séries documentais, a fim de identificar elementos que constituem padrões visuais em funcionamento na sociedade. Dessa forma, a primeira leitura consiste na compreensão do período em que os retratos foram produzidos e comercializados, bem como apontar quais foram as motivações do fotógrafo. A segunda análise evidencia os atributos formais expressos bidimensionalmente, enfatizando as indumentárias e os adornos que as mulheres utilizaram em suas respectivas retratações, a fim de descobrirmos pistas sobre suas histórias e os trabalhos que exerciam, configurando alguns dos aspectos abordados nas fotografias selecionadas para o presente artigo.

A fotografia enquanto documento, para Burke (2004), é vista como evidência da cultura material do passado, pois as imagens revelam ou implicam a respeito de ideias, atitudes e mentalidades em diferentes períodos, além de contribuir para a reconstrução da cultura cotidiana de pessoas comuns.

A análise que se segue baseou-se na fotografia de mulheres que estavam à margem do processo de "modernidade" almejado pelo governo, investigou diversos fatores, enfatizando aspectos da moda, a fim de compreender as personagens reais que compunham a população da cidade de Belém entre 1869 e 1875.

\section{No estúdio fotográfico de Fidanza}

Na segunda metade do século XIX, a cidade de Belém passa por profundas modificações em seu cenário urbanístico. Tal feito está diretamente relacionado ao projeto de modernização, triunfo que ficou conhecido como belle époque. Para Sarges (2002), essa situação histórica se deu ao fato de Belém concentrar a base logística da operação de comércio do látex, inserindo a região amazônica na esfera do capitalismo mundial, a partir do papel de fornecedora da matéria-prima.

Nesse período, a capital paraense utilizava a fotografia ${ }^{2}$ como meio de propaganda oficial do governo, a fim de mostrar os efeitos da "civilização" e também outro aspecto da cidade: as cenas do cotidiano, com tipos sociais pertencentes às camadas populares (PEREIRA, 2006). Foi nesse cenário que a cidade de Belém passa a registrar a presença de diversos fotógrafos ${ }^{3}$

\footnotetext{
2 A primeira fotografia reconhecida remonta ao ano de 1826 e é atribuída ao francês Joseph Nicéphore Niepce.

${ }^{3}$ Em 1846, o norte-americano Charles Fredricks inaugura o primeiro estúdio fotográfico de Belém.
} 
circulando e exercendo seus trabalhos em estúdios localizados nas principais ruas do comércio local.

Ainda que o processo fotográfico na região apresentasse dificuldades, como a distância para o deslocamento dos profissionais, a curiosidade sobre as experiências provocadas pela modernidade, aliada à imagem criada de um lugar grandioso e exuberante, bem como as narrativas místicas conferidas à região, atraía pesquisadores, viajantes e fotógrafos, que, em sua maioria, eram de origem estrangeira.

Quando adentramos no universo fotográfico oitocentista, que retratou escravizados, temos três tipos de representação em voga, que possuem suas raízes nos séculos anteriores: "o registro exótico/pitoresco, a representação das camadas populares e a iconografia de caráter cientificista, esta última muitas vezes baseada em teorias racistas" (HIRSZMAN, 2011).

Nesse período, o gênero retrato era o mais frequente, por ser um meio acessível de perpetuação da imagem do indivíduo, o que não ocorria na pintura por causa do seu alto custo para ser adquirida.

Quanto aos formatos de fotografias que circulavam na cidade de Belém, o chamado carte de visite 4 recebeu destaque. Tal padrão foi criado em 1854, pelo francês André Disdéri, que apresentava como características a de ser realizado em estúdio, medindo aproximadamente 6 x 9,5 cm, além de possuir um preço modesto, permitindo a pessoas de diferentes níveis sociais usufruir da novidade.

Um dos difusores dos cartões de visita em Belém foi o fotógrafo português Felipe Augusto Fidanza ${ }^{5}$, que, graças à sua obra, tornou-se a maior expressão da fotografia no Pará, destacando-se por documentar a paisagem urbana em processo de modernização, bem como cenas que retratam o cotidiano dos transeuntes nos mercados, nas praças e nas principais avenidas da cidade. Em suas fotografias, Fidanza revela crianças no mercado de trabalho, engraxates, carroceiros, vendedores ambulantes e mulheres, ocupando o primeiro plano das fotos tanto quanto os abastados da borracha, em uma alusão à igualdade tão sonhada pela República. Assim, os indivíduos pertencentes às camadas populares não foram colocados à margem dos registros fotográficos, exercendo papel preponderante para o estabelecimento da fotografia de rua (PEREIRA; SARGES, 2011).

Fidanza exerceu sua profissão até os 56 anos, quando cometeu suicídio ao atirar-se ao mar durante a viagem de Lisboa para Belém, no dia 20 de janeiro de 1903.

\footnotetext{
${ }^{4}$ Segundo Leite (2011) o cartão de visita apresenta como principal inovação o fato de ser produzido em série, a partir de um sistema de lentes múltiplas, o que permite ao cliente sair do ateliê fotográfico com uma coleção de imagens idênticas, que eram dadas como lembrança para parentes ou amigos ou, trocadas entre as pessoas, ou ainda, eram comercializadas pelos próprios fotógrafos, o que incentivou o surgimento dos colecionadores.

De acordo com Pereira e Sarges (2011) o primeiro trabalho profissional de Fidanza que ganhou destaque nacional foi o registro dos preparativos para a recepção da comitiva de D.Pedro II, o qual foi amplamente divulgado e, equivocadamente, atribuiu-se a chegada do fotógrafo a Belém junto com a comitiva do Imperador. Entretanto, as pesquisadoras relatam notícias de um jornal local que registram a existência do estabelecimento Fidanza \& Cia desde 1ㅇ de janeiro de 1867, confirmando que o estúdio fotográfico já estava em funcionamento há pelo menos nove meses antes da chegada da comitiva de D.Pedro II. Nesse sentido, é difícil atribuir uma data exata da chegada do fotógrafo a Belém.
} 
O ateliê, chamado "Fidanza \& Cia" e posteriormente "Photographia Fidanza" (figura 1), estava localizado na área central de Belém juntamente com outros estúdios fotográficos e demais estabelecimentos comerciais. Seu primeiro endereço foi o Largo das Mercês n. 6, entre os anos de 1867 e 1873, mais tarde, durante as décadas de 1880 a 1930, foi transferido para a Travessa Santo Antônio n. 21, e, depois, para a Rua Conselheiro João Alfredo n. 22 (PEREIRA, 2006).

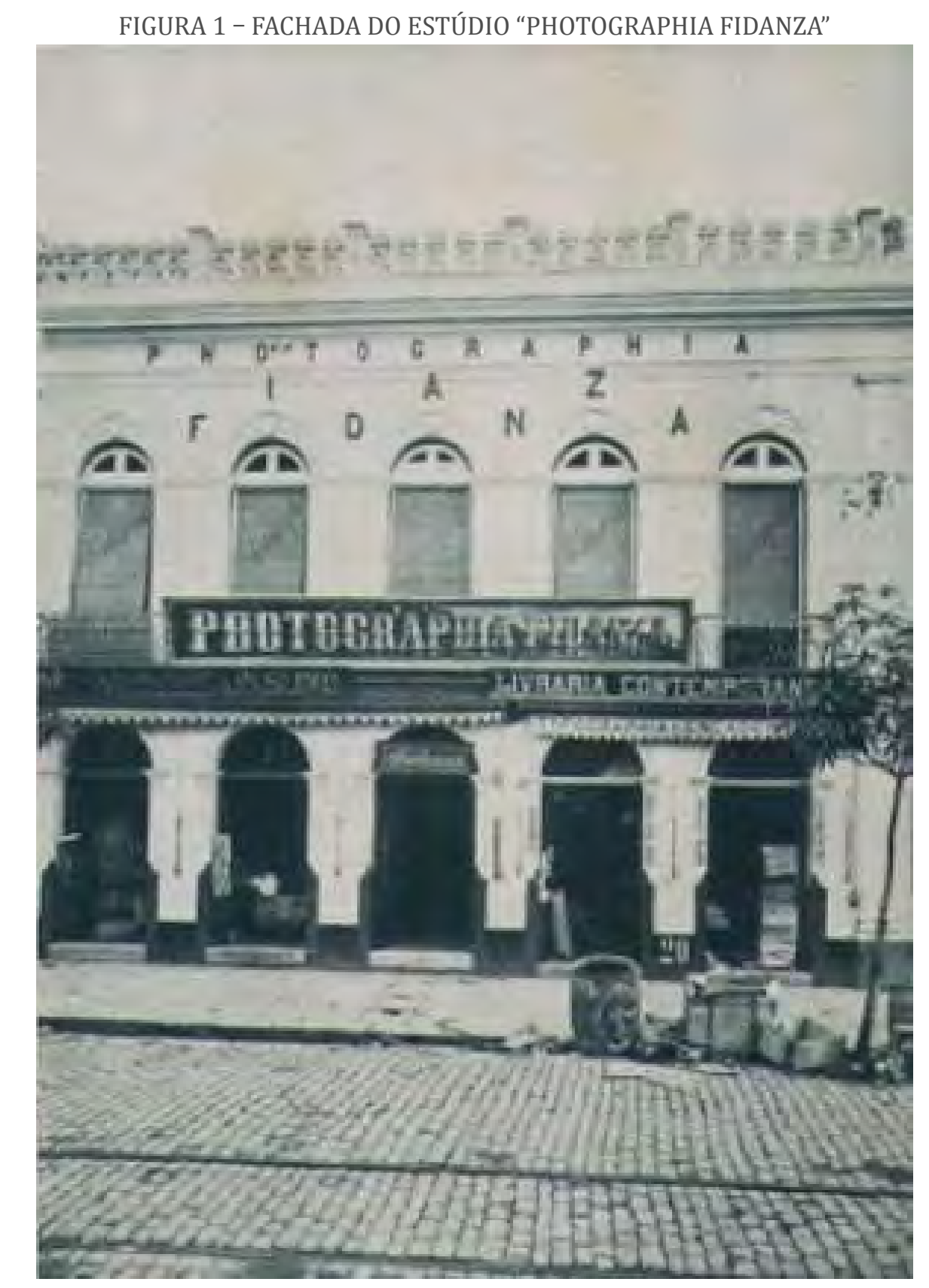

FONTE: CACCAVONI, 1898.

Álbum descritivo Annuario dello stato del Pará de 1898. Gênova: F. Armanino, p. 41. Acervo da seção de obras raras da Fundação Cultural do Pará Tancredo Neves. 
O cartão de visita foi um dos suportes escolhidos por Fidanza para retratar os tipos sociais que circulavam em Belém, explorando comercialmente tais personagens. Essas fotografias seguiam a tradição dos "tipos exóticos" que mostravam os "tipos populares" como indígenas e escravizados, e as figuras ilustres. De acordo com Kossoy e Carneiro (2002), essas imagens serviam para reforçar o sentimento da civilidade europeia e a consequente "incivilidade" dos trópicos:

Essas figuras "exóticas", reunidas provavelmente sob forma de "mostruários", prestavam-se à finalidade comercial pretendida pelo fotógrafo. De forma padronizada pela carte-de-visite, os personagens da coleção foram levados para a Europa como lembrança do Brasil, satisfazendo a curiosidade do cliente do Velho Mundo acerca da imagem do outro. (KOSSOY; CARNEIRO, 2002, p. 193-194)

Os profissionais que trabalhavam com a temática do "exótico" viram-no como um objeto de exploração comercial, em que as mensagens retratadas deveriam ser facilmente entendidas, como sugere Koutsoukos:

\footnotetext{
Nas cenas de estúdio, trataram os fotógrafos de colocar a referida ordem nas composições [...], e nas quais escolhiam com cuidado o que iam registrar, fazendo uso de signos, muitos dos quais podiam ser decodificados pelos que vissem os cartões. [...] um desses signos eram os pés descalços, que costumavam ser indícios de escravidão - pelo menos, esse signo era dessa forma entendido. Outros indícios da escravidão seriam a cor escura (que podia ligar a pessoa a uma história de escravidão) [...]. 0 tema do trabalho era outro indício de escravidão (ou pobreza) e foi a maior constante nesse tipo de foto, pois fazia parte do dia a dia da própria escravidão, mostrava o lugar da pessoa; porém, [...] indicava o grau de civilidade daquele indivíduo e exaltava sua dignidade. (KOUTSOUKOS, 2010, p. 122-123)
}

Também é válido apontar que, em algumas narrativas fotográficas, os clientes podiam introduzir a sua própria indumentária, "trazendo desde objetos cotidianos até roupa do dia a dia, ostentando traços da moda desejada, já que os ateliês oferecem vestimentas muitas vezes inacessíveis a eles" (LEITE, 2011, p. 29).

A partir desse contexto, procuramos analisar parte da obra de Fidanza por meio de cinco fotografias de diferentes mulheres, das quais destacamos o vestuário e os adornos corporais, utilizados por elas. Tal perspectiva advém da importância desses objetos, que podem ser compreendidos como um dos fatores de distinção social. Assim, essas peças possibilitam identificar alguns dos valores a elas associados no decorrer do tempo e a sua concordância com o contexto sociopolítico e cultural no qual foram produzidas e utilizadas.

Em um sentido amplo, Barnard (2003) conceitua que a moda pode ser compreendida como uma forma de comunicação entre os indivíduos de uma dada sociedade. Dessa forma, tal comunicação pode ser expressa pela aproximação e a troca entre os indivíduos, bem como pelo seu distanciamento, permitindo, assim, tanto a inclusão como a exclusão deles.

E no que tange à representação da moda para a sociedade do século XIX, era um dos meios de distinção, em que o uso de determinados signos, incorporava símbolos responsáveis 
por identificar funções, definir identidades e assinalar as distâncias entre os indivíduos, criando, assim, uma comunicação não verbal, em que o prazer de exibir-se ao olhar do outro era imprescindível em todas as esferas sociais. Nesse mesmo século, a moda se espalhou por todas as camadas sociais, tendo em vista que os desejos de prestígio crescem juntamente com as necessidades de liderança, a moda encontrará diversos meios para torná-los visíveis (SOUZA, 1987).

Sob esse aspecto, podemos salientar que a sociedade belenense do século XIX também estava dividida quanto à moda: enquanto a elite financeira se empenhava em imitar os hábitos e a moda europeus, como, por exemplo, o uso de roupas pesadas e em tons escuros, os (ex-)escravizados, ribeirinhos e trabalhadores em geral negavam essa estética, adotando trajes mais leves e em cores claras, em decorrência da própria realidade climática da região, por serem mais simples e permitirem a movimentação dos corpos em condições de trabalho e por serem de fácil acesso, o que fica evidenciado nas fotografias analisadas ao longo do presente texto.

A distinção também se dava por meio da qualidade dos tecidos ${ }^{6}$ usados para compor os trajes da população. Nesse sentido, eles também eram lidos como símbolos da presença ou da ausência de riqueza. Drumond (2008) afirma que, no vasto mercado de tecidos, os panos finos eram destinados à elite, enquanto os mais grossos ou rústicos eram utilizados na vestimenta dos escravizados e também na confecção de sacos para guardar mercadorias.

As fotografias que serão analisadas ao longo do texto estão em plano médio (com o modelo retrato de corpo inteiro, geralmente centralizado, e com espaço relativo em volta), o que permite a exploração do cenário e a apresentação de certos símbolos de status (KOUTSOUKOS, 2010). Entretanto, podemos observar que as modelos estão no mesmo lugar: o piso e um fundo artificial, o qual sugere ser um equipamento do estúdio de fotografia de Fidanza, o mesmo repete-se nas cinco fotografias estudadas. Tal cenário, além de padronizar as imagens, não possui nenhuma informação que possa evidenciar uma posição de destaque na sociedade, mas ressalta e valoriza a figura feminina como principal elemento do retrato.

Mas por que construir uma cena em um estúdio, quando ela poderia ser facilmente retratada no espaço público das cidades? Para Koutsoukos (2010), a construção de uma cena em estúdio tinha a ver com a ideia de autorepresentação daquelas pessoas e também com o nível de controle que o profissional exerceria sobre o trabalho, pois ali ele tinha o tempo e o material para ajeitar, enquadrar, iluminar o local e o retratado.

Assim, o estúdio fotográfico para a mulher negra torna-se a extensão da rua. "No entanto, o fotógrafo não mostra o contexto da cidade, ao contrário, seus 'modelos' aparecem no estúdio. Isso não quer dizer que não se tenha, nessas representações, a dinâmica da cidade codificada em gestos, poses e arranjos negociados" (BELTRAMIM, 2009, p.39). Nesse sentido, ao mesmo tempo que essas mulheres são retiradas do cenário urbano e levadas para uma sala, encenam algo que costumam fazer diariamente, descontextualizadas, elas se tornam, desse modo, atrizes de suas próprias histórias, como em uma mímica (HIRSZMAN, 2011).

\footnotetext{
${ }^{6}$ É um produto manufaturado, em forma de lâmina flexível, resultante do entrelaçamento, de forma ordenada ou desordenada, de fios ou fibras têxteis entre si. 0 que qualifica um tecido como inferior (ao qual denominaremos grosso/rústico), mediano ou superior (fino/muito fino) é, sobretudo, a relação entre o tipo de fibra com que é produzido (animal ou vegetal) e a ordenação de dois sistemas de fios que se cruzam perpendicularmente, em ângulos de 90o, formando assim sua superfície (DRUMOND, 2008).
} 
Na fotografia "Cabocla" (figura 2) Fidanza retrata uma mulher jovem, de corpo inteiro, ligeiramente virada para a esquerda. A modelo não encara o fotógrafo, orientação que pode ter sido dada por ele mesmo. Ela tem o tom de pele escuro e traja uma blusa de gola alta, com mangas e botões, uma espécie de folho em cima da barriga e uma saia longa com poucos detalhes, todas em cores claras. A cabocla segura em seu braço esquerdo, uma bolsa em forma de cesta com tampa e, para compor o penteado elaborado à moda europeia, ela porta arranjos de flores em seus cabelos. 0 penteado da modelo pode ser lido inicialmente como emprestado "do outro", caracterizando uma tentativa de trilhar seu caminho dentro de uma sociedade branca, exigente e racista (KOUTSOUKOS, 2010, p.16).

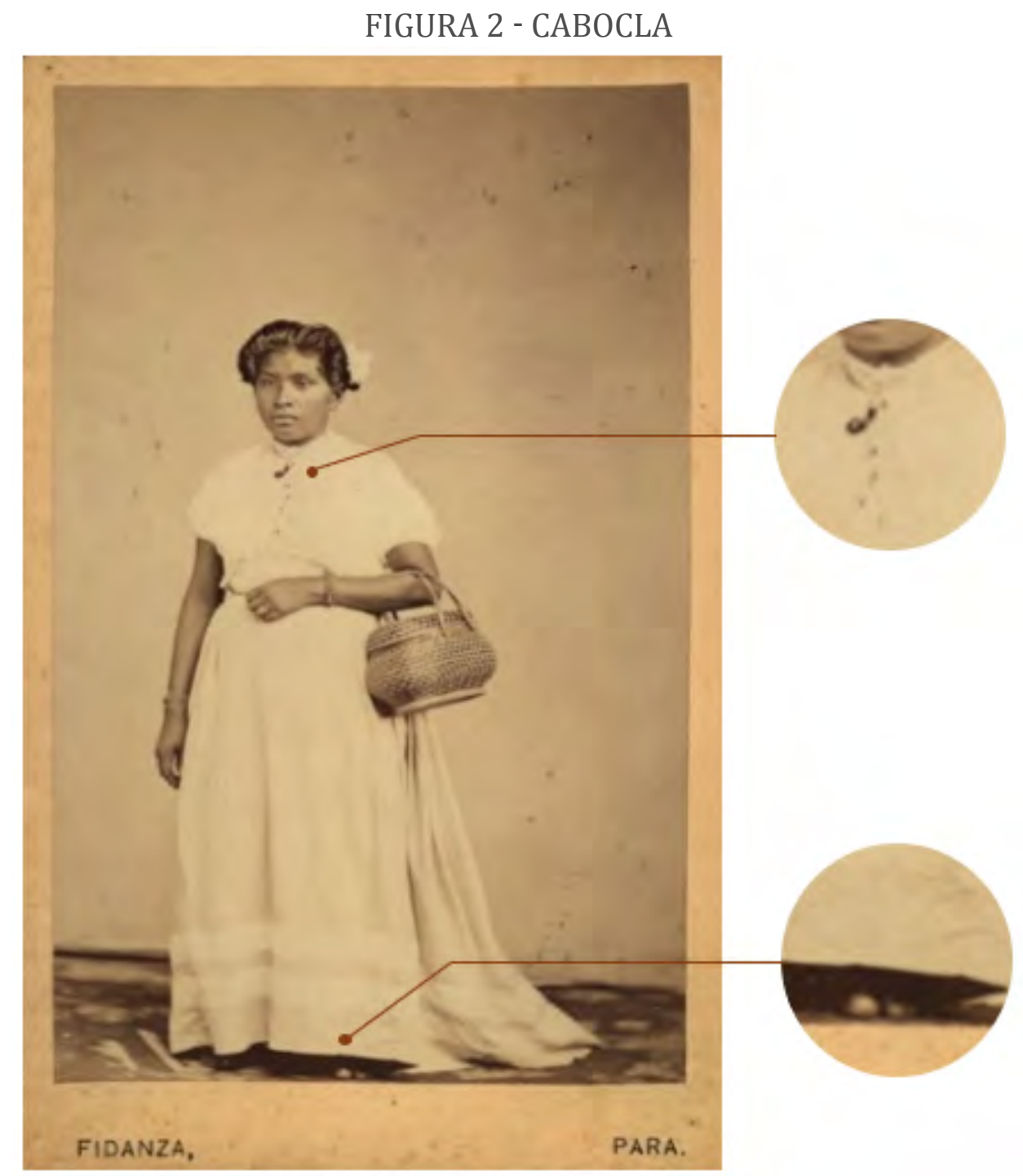

FONTE: Fotografia de Felipe Augusto Fidanza. Pará, 1869-1875.

Com detalhes para a mecha de cabelo e do pé descalço.

Disponível em: https://ifl.wissensbank.com/esearcha/browse.tt.html.

Acesso em: 20 fev. 2020. Imagem obtida mediante download de arquivo. 
Dessa forma, o uso de diversos códigos de representação, sobretudo dos europeus, dá-se principalmente pela necessidade de essas mulheres tentarem ser aceitas, ou ao menos toleradas pela sociedade e, assim, obter o seu espaço.

Essa mulher também utiliza pulseiras nos dois braços, um anel na mão esquerda e brincos. Ao observamos a imagem, vemos a existência de um "ponto" escuro, que pende em seu pescoço, realçado diante da vestimenta clara da modelo. Ainda que a presente imagem não tenha resolução que permita identificar tais nuances, esse detalhe pode ser uma mecha de cabelo, podendo ser considerada uma joia de luto.

Tal especificidade configura as chamadas joias de luto, que nasceram por volta do século XVII e atingiram sua popularidade na Europa durante a era vitoriana, no século XIX, quando broches ou pendentes com mechas de cabelo eram mesclados a camafeus, colares e pulseiras. Tradicionalmente, as joias de luto carregavam uma grande carga semântica e serviam para três propósitos: memória de uma pessoa querida e amada; "memento mori", um lembrete da morte e da fragilidade de todos os seres vivos; e símbolo de status social.

De acordo com Schmitt (2017), as sociedades, ao longo da História, desenvolveram diversos rituais pós-morte, a fim de colaborar com a compreensão e elaboração do sentido da perda e do fim da vida dentro de um grupo social. A externalização do sofrimento, deveria fazer jus ao vínculo com o morto, enaltecendo sua memória diante de todos (ainda que, para muitos, fosse apenas uma obrigação). A aparência diferente daquela de todos os outros dias tornava-se símbolo da reclusão causada pela tristeza (verdadeiramente ou não) sentida. Ao virar norma de civilidade, o luto se transformou em um tempo necessário de recolhimento que a sociedade impõe e que é respeitado por ela. A cor e o tipo de roupa que se veste durante e após os ritos fúnebres são dos aspectos determinantes do luto. Variável no percurso histórico e nas civilizações, a indumentária de luto no Ocidente, pelo menos a partir da Idade Média, caracterizou-se pelo predominante uso da cor preta e outros tons escuros.

Conforme elucida Santos (2012, p.7), "ser civilizado" no Oitocentos significava conhecer e utilizar os modelos europeus para se apresentar, a fim de construir a aparência e a imagem em concordância com os ditames da moda, demarcando a distância entre os que pertenciam à boa sociedade e as pessoas comuns. Nesse sentido, podemos inferir que tais joias de luto eram usadas por uma parcela da população, apenas por aqueles que podiam encomendar e pagar por esses adornos.

Ainda que a "Cabocla" de Fidanza porte símbolos de status como as joias, também é sugerida a provável condição de escravizada, haja vista que ela parece ter sido retratada sem calçados. Na fotografia, também podemos observar o jogo dicotômico da apresentação da modelo: ao hibridizar códigos visuais característicos de sua posição na sociedade (escravizada) com elementos de pertencimento à camada mais abastada (uso de joia de luto), o que a imagem sugere é o seu possível sentimento de luto.

Mas será que de fato a modelo retratada estava em período de luto? Pois, como exposto anteriormente, as pessoas que perdiam um ente querido vestiam preto por um bom 
tempo, enquanto que a mulher fotografada usa vestimentas claras, remetendo a uma nítida oposição a essa regra social. E como já citado, o grupo que compunha as camadas populares, geralmente, portava roupas claras, pois eram mais baratas e de fácil acesso, o que ajuda a entender o uso dessas peças em detrimento das pretas.

Contudo, também não devemos esquecer que ela está sob a condição de escravizada, e, por conseguinte, seus recursos são mais limitados. Por esse motivo, pode expressar seu momento de luto portando somente o colar com mechas de cabelos de uma pessoa que havia perdido mesmo com parcas condições financeiras, ela pode ter encomendado e pago por tal adorno em uma tentativa de estabelecer um laço de conexão e lembrança com a suposta pessoa amada.

Outra possibilidade de interpretação é que tal joia pode ter sido posta na modelo, apenas como adorno, para fins de "enfeite" e não necessariamente com as mechas de algum ente seu que havia falecido, pois, em alguns casos, o fotógrafo podia criar um cenário.

Segundo Koutsoukos, “os retratos deviam deixar explícita a posição que a pessoa ocupava, ou que queria dar a entender que ocupava, e geralmente, apesar de se tratarem de cenas 'construídas', ou por isso mesmo, costumavam deixar claro o papel de cada um" (KOUTSOUKOS, 2010, p. 95), para se tornarem verdadeiras mensagens que poderiam ser facilmente compreendidas pelos parentes e amigos que as recebiam. Dessa forma, pode-se sugerir que existia uma contribuição das modelos, junto ao fotógrafo, na construção do seu retrato e, a partir dessa hipótese, utilizamos essas fotografias como mais uma fonte de pesquisa, para observamos as representações dos vestuários e adornos que eram usados nas ruas.

Logo, neste artigo, trato essas mulheres como sujeitas das imagens, tendo a oportunidade de autorrepresentação e não apenas como meras modelos das fotografias souvenirs, ainda que em alguns casos os retratos de escravizados não fossem encomendados por eles.

No cartão de visita "Cafusa" (figura 3), Fidanza expõe uma mulher jovem de corpo inteiro. Diferentemente da imagem anterior, a modelo olha para o fotógrafo de frente, mesmo que esteja com a cabeça levemente abaixada. Ela segura um prato no quadril com o braço esquerdo, o que pode sugerir que trabalhava com tarefas domésticas. Sua vestimenta é composta por uma blusa decotada, que deixa à mostra seu ombro direito, enquanto a saia é ligeiramente puxada para cima, evidenciando seus pés descalços. Tal composição da vestimenta clara contrasta com o tom de pele da mulher. Notamos que a modelo possui os cabelos muito armados e repartidos ao meio, com flores brancas. 


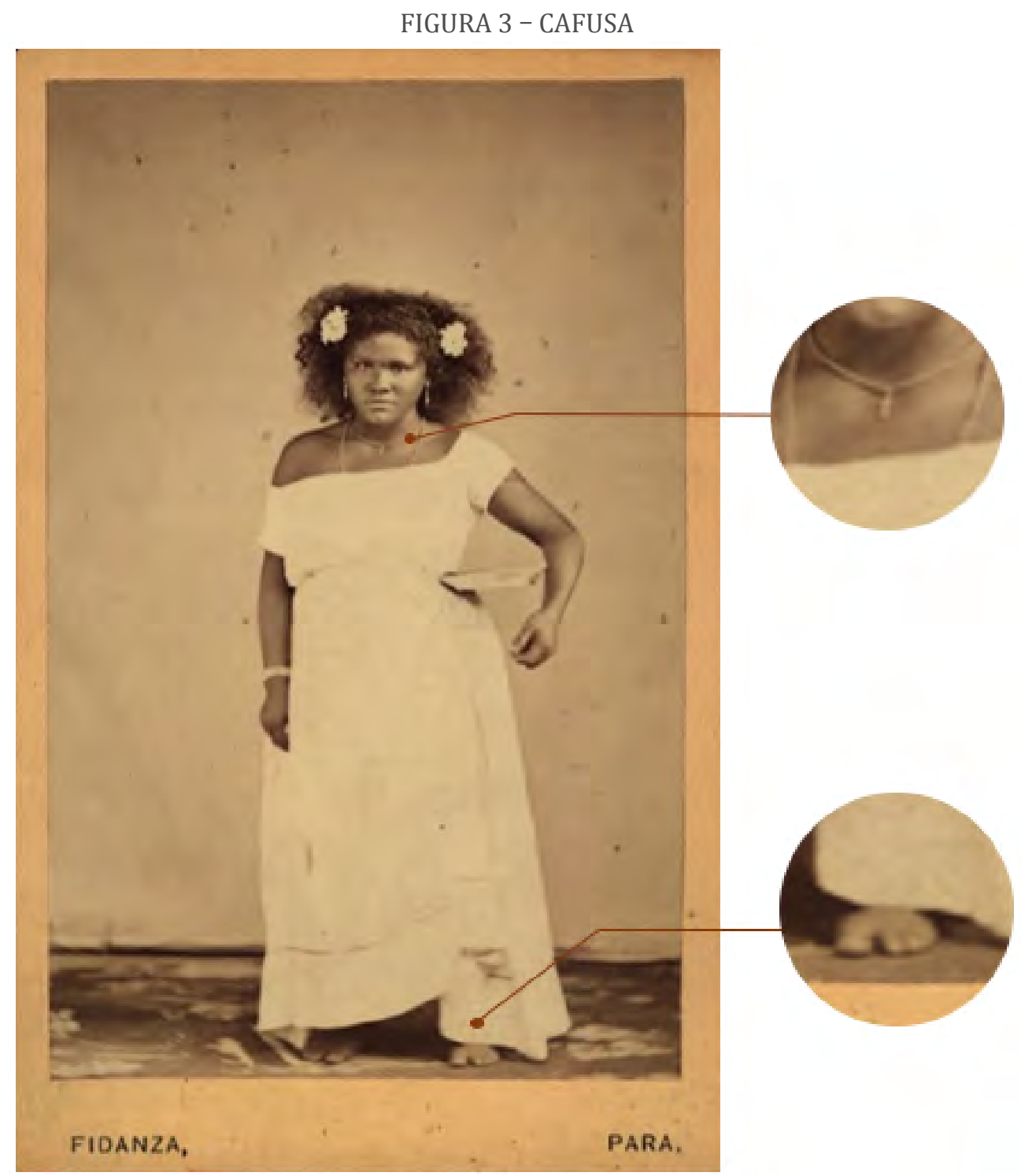

FONTE: Fotografia de Felipe Augusto Fidanza. Pará, 1869-1875.

Com detalhes da pequena cruz e do pé descalço.

Disponível em: https://ifl.wissensbank.com/esearcha/browse.tt.html. Acesso em: 20 fev. 2020. Imagem obtida mediante download de arquivo.

Quanto aos adornos corporais, a mulher fez uso de brincos longos, uma pulseira no braço direito e dois colares em volta do pescoço: um maior e outro menor, que possui como pendente uma pequena cruz, indicando, em um primeiro momento, sua crença no cristianismo. Porém, ao observamos mais detalhadamente a imagem, podemos sugerir uma possível sincretização religiosa por parte da fotografada, pois o uso de blusa na cor branca remete às condições recorrentes aos paramentos utilizados nos cultos afro-brasileiros, presentes ainda hoje.

Em "Vendedora de frutas no Pará" (figura 4), podemos observar a criação de um cenário um pouco mais elaborado do que o das fotografias anteriores. Ainda que seja o mesmo fundo artificial, Fidanza leva para o seu estúdio elementos que indicam o tipo de trabalho que a mulher exercia, dando sentido ao tema fotografado. A variedade de frutas, entre elas 
bananas, cupuaçu, cacau (castanhas?), está disposta em tigelas de barro e um cesto; também observamos na composição a existência de uma cuia vazia.

\section{FIGURA 4 - VENDEDORA DE FRUTAS NO PARÁ}

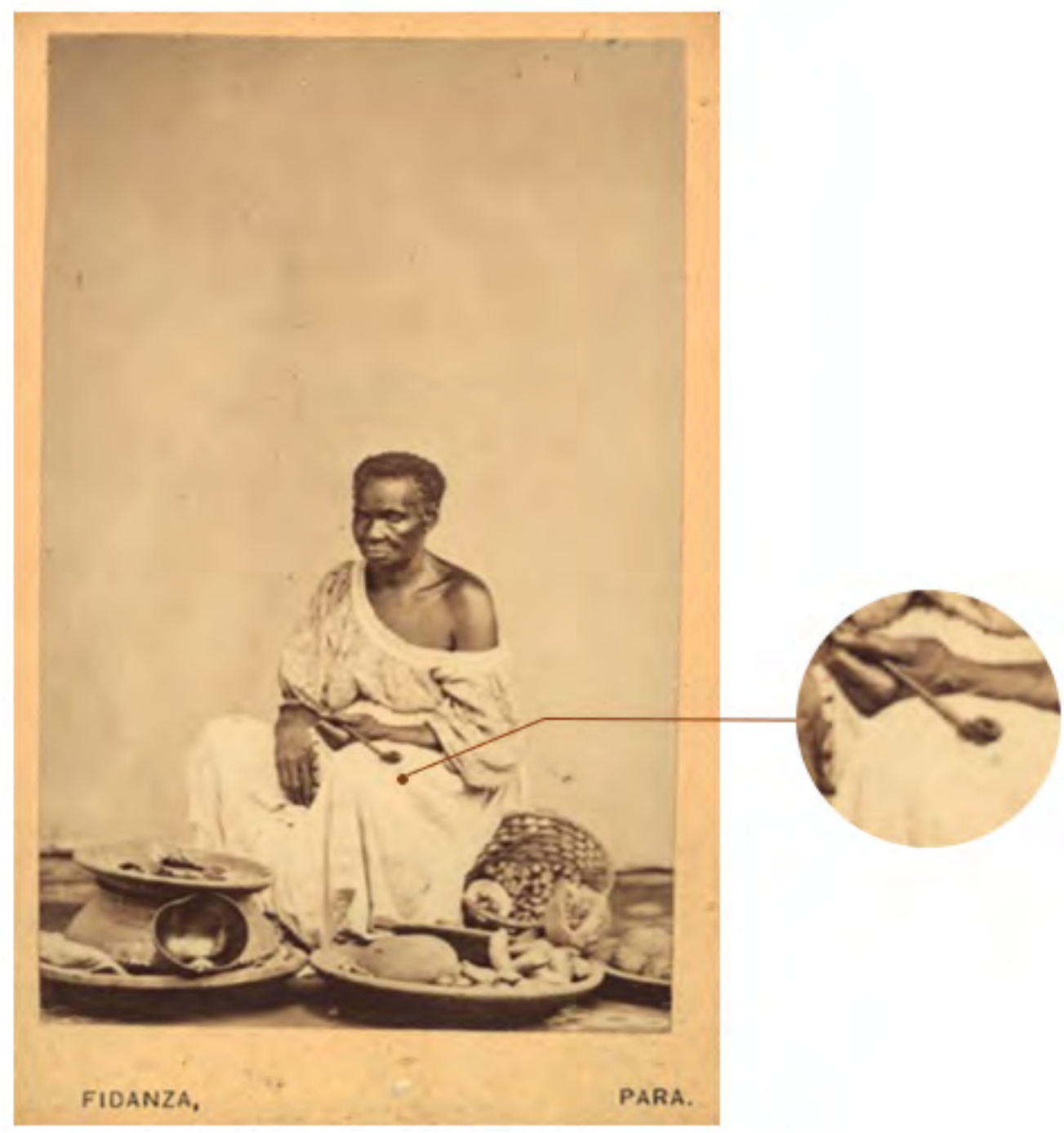

FONTE: Fotografia de Felipe Augusto Fidanza. Pará, 1869.

Com detalhe do cachimbo.

Disponível em: https://ifl.wissensbank.com/esearcha/browse.tt.html. Acesso em: 20 fev. 2020. Imagem obtida mediante download de arquivo.

No que concerne à vestimenta, a vendedora traja uma blusa com mangas longas, cujo decote rendado evidencia seu ombro esquerdo, e uma longa saia na cor branca. É interessante notarmos a dualidade presente nessa imagem: a modelo mais velha foi fotografada com a cabeça inclinada, esboçando um olhar melancólico, o qual não encara Fidanza. Ela 
aparece em segundo plano, sentada atrás das frutas. Porém, por revelar parte de seu ombro, subentende-se certa sensualidade, como relata Beltramim:

[...] associavam a mulher negra à promiscuidade, a uma sensualidade exacerbada, diferenciando-as das mulheres brancas, que praticamente reclusas à esfera da vida privada, ao lar, ficavam menos expostas, eram então tidas como de boa moral e honestidade. Na rua estavam as mulheres negras, excluídas da proteção dos lares e de seu anonimato. Suas identidades foram assim constituídas, na dinâmica do trabalho, nas tensões diárias onde sobreviver era tão pesado quanto aparentemente lascivo. (BELTRAMIM, 2009, p. 228)

Diferentemente das outras modelos, a vendedora de frutas de Fidanza não possui nenhum adorno corporal, entretanto existe um ponto que merece destaque na composição fotográfica, a presença de um comprido cachimbo, seguro no colo da retratada pela mão esquerda, demonstrando uma faceta do que era considerado "exótico", pois, segundo Koutsoukos (2010, p. 123), os cachimbos eram comuns de serem "pitados", principalmente entre as negras africanas.

No mercado da fotografia desse período, existia a categoria do exótico, na qual escravizados e/ou forros pobres posavam como modelos e as imagens eram vendidas como souvenir. Koutsoukos (2010) salienta que os profissionais desse meio viram em tal tema um objeto de exploração comercial de retorno fácil e rápido, em que essas fotos seguiam o circuito do comércio de bens exóticos, muito apreciado na Europa na época. Imagens similares estavam sendo produzidas em diferentes locai por fotógrafos envolvidos em expedições a países nos quais houvesse elementos que merecessem a definição de "exótico", a fim de assegurar o interesse na fotografia que produziam.

Como exposto anteriormente, em alguns casos, poderia existir uma colaboração das modelos na composição fotográfica, estendendo-se também para a temática do exotismo. Ainda que, na Europa, fosse considerado "exótico" observar a fotografia de uma mulher segurando um cachimbo, para elas, esse era o universo no qual estavam inseridas e submersas. Assim, ao considerar algo "exótico", podemos pensar no princípio da relativização, pois o exótico depende invariavelmente da distância social, que tem como componente a marginalidade alimentada de um sentimento de segregação (DAMATTA, 2010).

Em "Mulata" (figura 5), Fidanza retrata uma mulher jovem, de corpo inteiro e pele escura. Aqui, não vemos uma posição de subordinação ou subjugação, pois a modelo encara o fotógrafo e o observador com certa altivez. Ela traja um vestido branco de mangas, com decote que evidencia parte de seu ombro, revelando a erotização do seu corpo, o qual era observado pelas suas características raciais e sexuais. Beltramim (2009) também comenta que essa prática era amplamente explorada em aquarelas, pinturas e fotografias, ao apresentar uma vasta representação erotizada que atravessou o século XIX. 


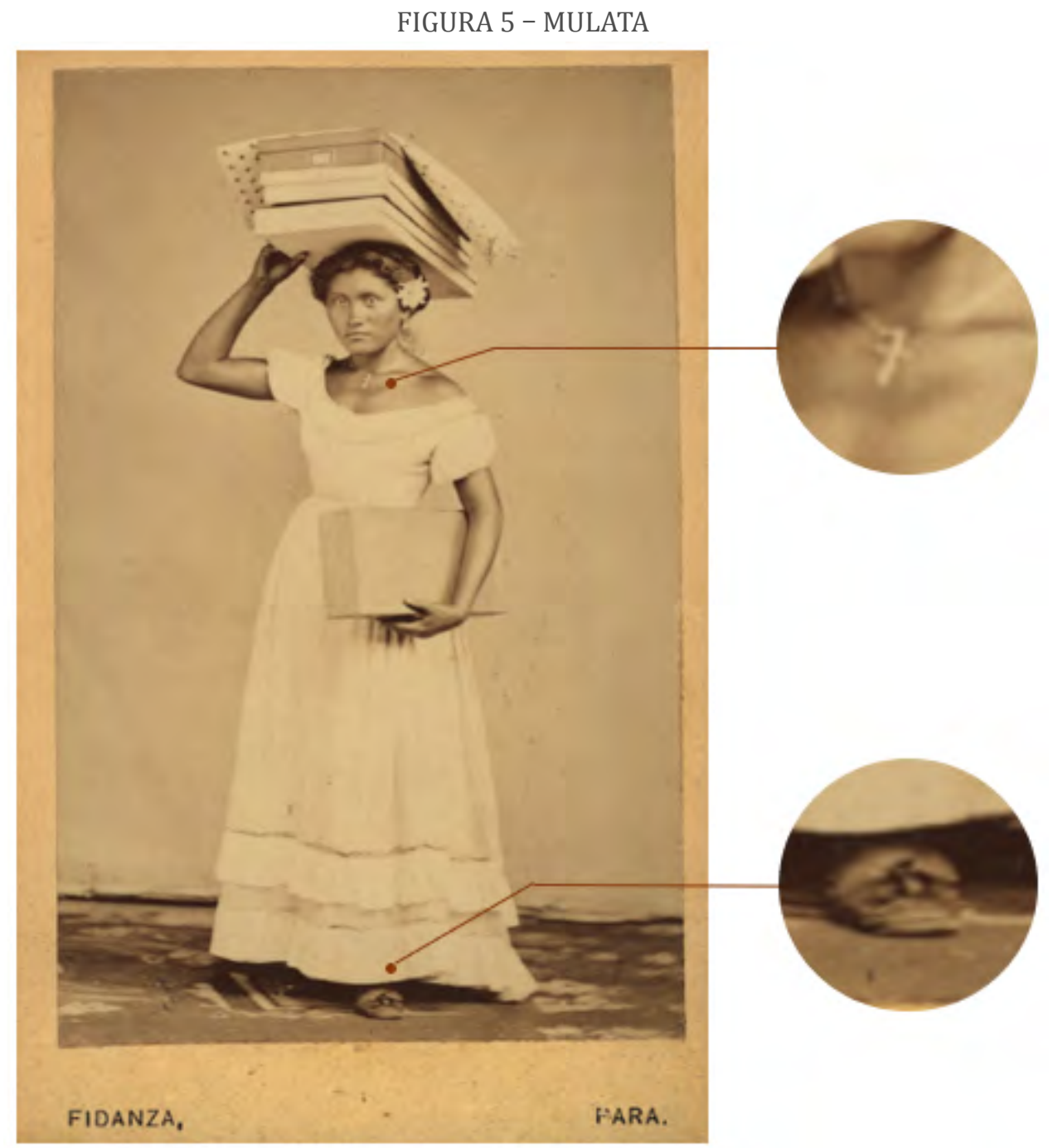

FONTE: Fotografia de Felipe Augusto Fidanza. Pará, 1869-1875.

Com detalhes da cruz e do pé calçado.

Disponível em: https://ifl.wissensbank.com/esearcha/browse.tt.html.

Acesso em: 20 fev. 2020. Imagem obtida mediante download de arquivo.

0 vestido é marcado na cintura e apresenta dois folhos na saia. A modelo segura duas caixas na cabeça e um tecido dobrado que está sobre uma delas. Ela também porta uma caixa debaixo do braço esquerdo. Conforme a descrição da referida fotografia pela plataforma do Instituto Leibniz, que divulga as imagens aqui expostas, é sugerido que eram caixas de roupas, o que nos concede pistas sobre a possível atividade de trabalho da mulher, podendo ser vendedora, costureira, engomadeira ou lavadeira.

Outro ponto que chama atenção é um possível uso de sapatos, o que nos permite interpretar sua condição de liberta, caso tenha sido escravizada em algum momento de sua vida, ou ainda que a "mulata" fotografada por Fidanza não tenha nenhuma relação com a escravidão. Quanto ao adorno que ela carrega, podemos observar ao redor do pescoço o uso de uma corrente com um pendente de cruz, o que remete ao cristianismo e à devoção católica, condensando, nessa imagem, a história de Jesus Cristo. 
Na fotografia "Mulata" de Fidanza, podemos observar uma contradição: ainda que a modelo esteja usando um símbolo do cristianismo, sabemos que a moral cristã oprimia as manifestações corporais, impondo às mulheres brancas comportamentos contidos, enquanto que, por outro lado, o corpo das mulheres negras e mulatas era amplamente erotizado, $o$ que fica evidenciado na afirmativa de Beltramim:

No início do século XIX, quando os primeiros viajantes, logo após a chegada da família real, começaram a retratar os costumes brasileiros, a "liberdade com o corpo revelada" por essas mulheres foi vista com certa "estranheza", sendo depois sublinhada como puro fetiche. (BELTRAMIM, 2009, p. 227)

Assim como nas imagens das modelos "Cabocla" e "Cafusa", capturadas pelas lentes de Augusto Fidanza, a "Mulata" tem em seu cabelo um arranjo de flores, tal costume de enfeitar e perfumar os cabelos revela-se habitual entre as mulheres paraenses, como citado por João Affonso, em sua obra "Três séculos de moda": "[...] 0 cabelo, ondulado e fofo, repartia-se em duas fartas trunfas, e de cada lado, encaixados no alto de cada orelha, dois grandes ramalhetes de rescendentes jasmins" (AFFONSO, 1976, p. 223). Essa descrição aparece logo após o desenho da "Mulata Paraense" (figura 6), que fora produzido por Affonso em 1916, a partir da representação de David O. Widhopff, de 1895 (à esquerda), e do registro ao natural de Affonso, de 1885 (à direita).

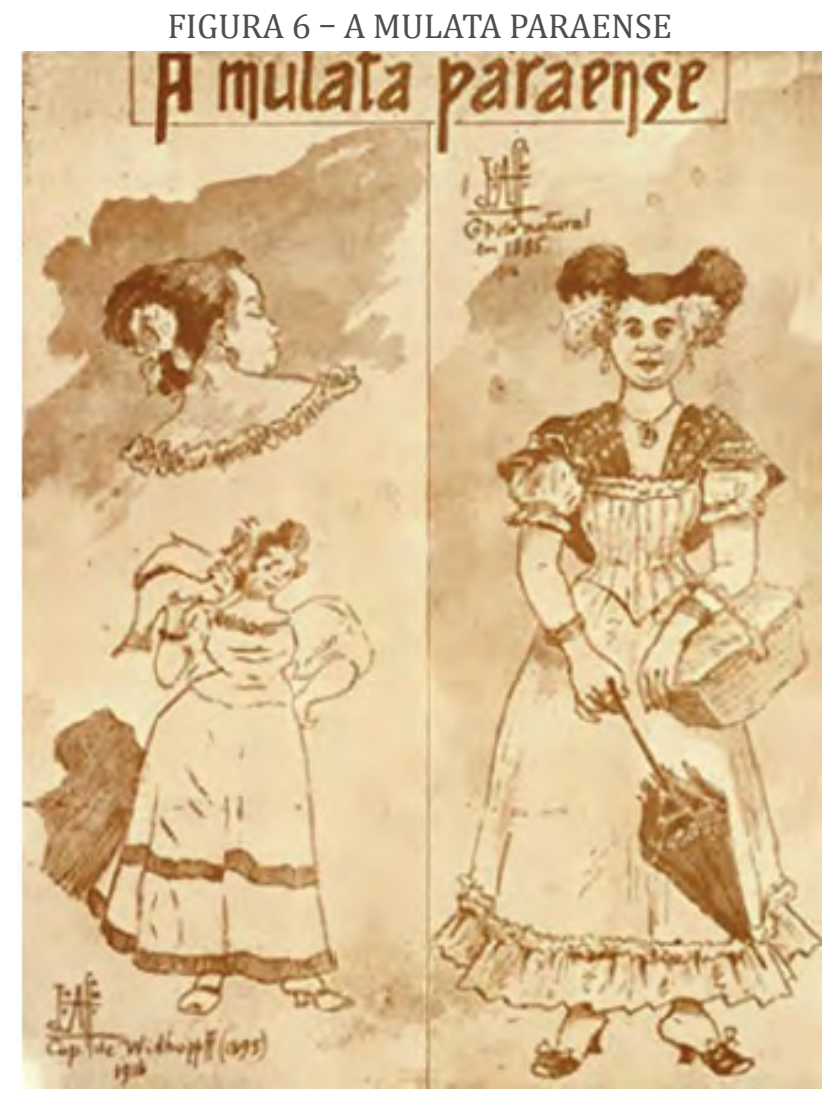

FONTE: AFFONSO, 1976.

Ilustração de João Affonso, em 1916, a partir do desenho de David O. Widhopff, de 1895

(à esquerda) e do registro ao natural de Affonso, de 1885 (à direita). 
O viajante inglês William Edwards, em seus escritos realizados a partir de suas viagens pelo Rio Amazonas e sua estadia no Pará, chama a atenção para o movimento da cidade em dias de procissão e festividade religiosa, pois era o momento em que as mulheres paraenses vestiam seus melhores vestidos e se adornavam com flores no cabelo. "A Mulata Paraense" não ocupava as varandas das casas de comércio e residências destinadas às famílias abastadas da região, pois seu lugar era em outros cômodos da casa ou na própria rua. Sobre a festa mais importante e grandiosa da cidade, o Círio de Nazaré, celebração religiosa que ocorre em Belém desde 1793, Edwards descreve a divisão entre as classes sociais dentro da própria igreja:

\footnotetext{
A missa das oito horas é notificada pelos fogos de artifício, e aqueles que se importam frequentam a capela. Dentro estão as mais elegantes senhoras e alguns cavalheiros; fora, no grande pórtico aberto, estão sentadas no chão as mulheres negras e as indígenas, vestidas de branco, com flores no cabelo e excessivamente perfumadas com baunilha. (EDWARDS, 1847, p.185)
}

Assim, com base nas fotografias de Fidanza, com os relatos de João Affonso e Edwards, entre outras obras que não estão citadas no presente artigo, podemos afirmar que o uso de flores naturais nos cabelos configurou-se em um costume social das mulheres pertencentes às camadas populares, durante o século XIX e a primeira metade do século XX, revelando o cuidado sensorial com seus corpos, a fim de perfumá-los e evidenciar a sua feminilidade, bem como estava associada à questão higienista da população.

\footnotetext{
A associação entre as flores e o seu perfume [...] se relaciona com a proposta higienista das reformas urbanas, que tinha como propósito esconder mazelas urbanas, como o mau cheiro, causado pela precariedade da rede de esgotos e pela falta de higiene. (IMADA, 2019, p. 46-47)
}

Carvalho (2008) também esclarece sobre a afinidade culturalmente entendida das flores como intrínseca entre ao feminino: as mulheres são representadas em fotografias ao lado de vasos de flores, com roupas estampadas com motivos florais; as flores enfeitavam o interior das salas e eram um sinal da presença permanente da mulher; além de estarem presentes nas estampas dos estofados das salas, nos acessórios pessoais e nos objetos de guardar, também eram utilizadas para descrever qualidades e sentimentos femininos; e perfumavam as roupas brancas guardadas em sachês nas gavetas. As mulheres eram frequentemente comparadas às flores, portanto elas faziam parte do universo de objetos com os quais se excitava a imaginação e a fantasia, território e arte das mulheres refinadas.

Outra possível relação do uso de arranjo de flores no cabelo remete-nos à ascensão do estilo Art Nouveau ${ }^{8}$ na sociedade burguesa dos fins do século XIX. Sua chegada ao Brasil

\footnotetext{
7 Tradução nossa para: “At eight o'clock servisse is notified by the ascent of rockets, and those who care attend the chapel. Within are the more fashionable ladies and a few gentlemen; without, in the large open pórtico, are seated upon the floor the black and Indian women, dressed in white, with flowers in their hair, and profusely scented with vanilla".

8 "A qualidade visual característica do Art Nouveau é uma linha orgânica, similar às feições das plantas [...] Gavinhas, flores (como a rosa e o lírio), pássaros (particularmente pavões) e a forma humana feminina eram motivos frequentes dos quais essa linha fluida era adaptada". (MEGGS; PHILIP, 2009, p. 248)
} 
se deu por meio da importação de objetos, da moda e de revistas. Posteriormente, o estilo foi absorvido fortemente pela arquitetura e pelo segmento das artes gráficas, como é o caso dos relatórios de governo, chamados "Álbum do Pará", nos quais eram registrados os feitos administrativos dos governadores do Estado; e de algumas revistas, como a carioca Kosmos. Essas publicações eram responsáveis por ditar os parâmetros de bom gosto e elegância a serem seguidos pelas suas leitoras em seus passeios pelos recém-conquistados espaços públicos do centro urbano em crescente modernização. Como podemos observar em Imada "os trajes, os acessórios e os penteados afrancesados, presentes nas fotografias [da revista Kosmos], compõem um conjunto de alto valor estético para a leitora da revista" (IMADA, 2019, p. 109).

Assim, a estética Art Nouveau esteve muito presente na moda feminina do século XIX, sendo comum a prática entre as mulheres brancas utilizar ornamentos com a temática de itens da natureza, costume que foi ressignificado pelas escravizadas e pertencentes das classes mais baixas ao portar flores naturais em seus cabelos, por causa da sua acessibilidade.

Para finalizarmos, na fotografia de Fidanza intitulada "Negra" (figura 7), vemos uma jovem de pele escura retratada de corpo inteiro, representada frontalmente. Assim como na imagem anterior, a modelo olha fixamente para o fotógrafo. Ela segura um vaso na cabeça com a mão direita e uma pequena cesta fechada no braço esquerdo.

\section{FIGURA 7 - NEGRA}

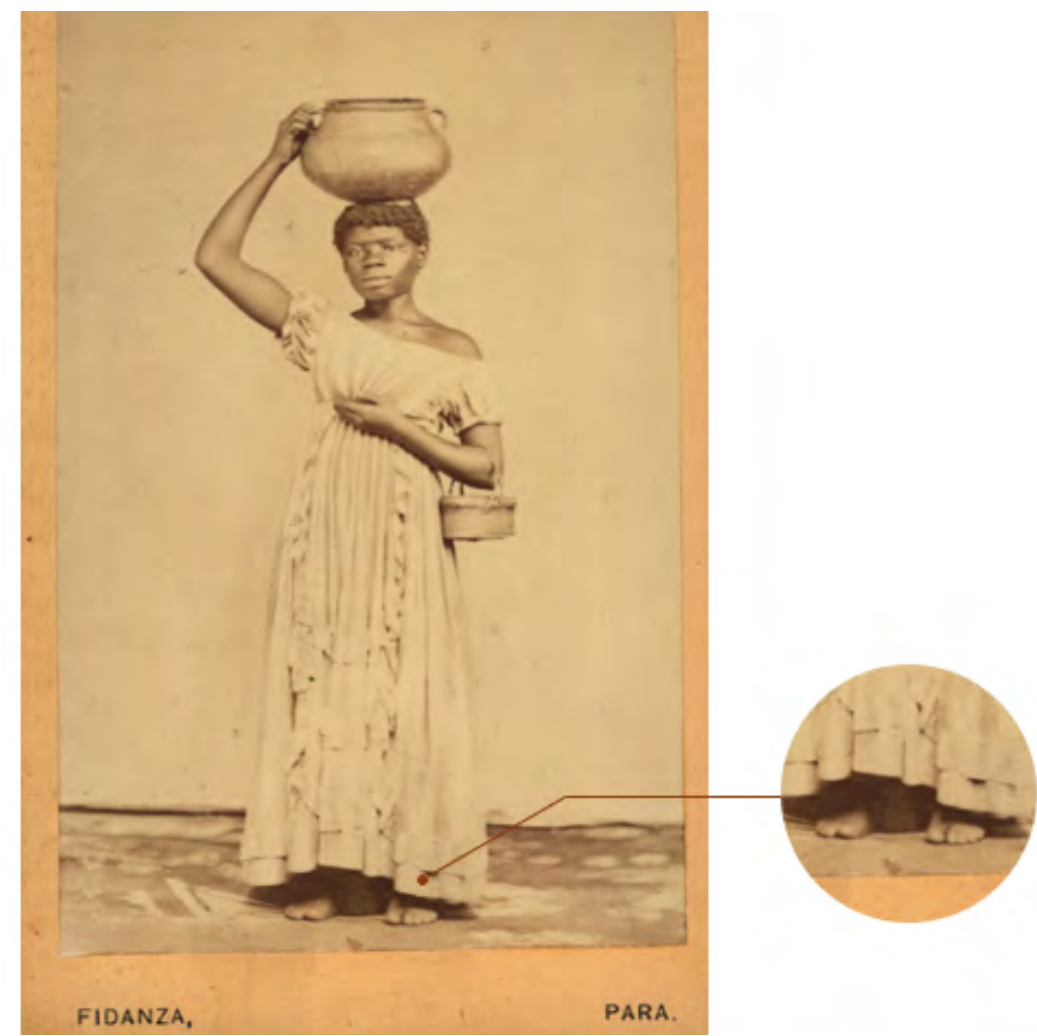

FONTE: Fotografia de Felipe Augusto Fidanza. Pará, 1869. Com detalhe dos pés descalços.

Disponível em: https://ifl.wissensbank.com/esearcha/browse.tt.html. Acesso em: 20 fev. 2020. Imagem obtida mediante download de arquivo. 
A "Negra" usa um vestido longo, de cor clara, com folhos e certa simplicidade em seu corte. Quanto à posição da mão esquerda da fotografada, ela pode sugerir que está erguendo a barra frontal do vestido ou ainda que a barra pode ser levemente mais curta na frente. Tal detalhe pode ter sido proposital, pois ajuda a evidenciar os pés descalços, e, consequentemente, sua posição de escravizada na sociedade. Outro ponto que também merece destaque é que a mulher deixa o ombro esquerdo à mostra, sugestionando certa malícia, o que reforça o estereótipo do exotismo e da sensualidade, pilares que contribuíram para fundamentar ainda mais a diferença, a hierarquização e a discriminação dos corpos pretos que circulavam pelas ruas de Belém.

Conforme elucida Cristina Cancela (1997), a liberdade dos movimentos corporais, a beleza dos atrativos físicos realçados em um descuidado vestir, a malícia muitas vezes refletida no olhar, são algumas das imagens com que escritores, jornalistas e memorialistas representavam as mulheres das camadas populares, como as "mamelucas", as "índias" e as "caboclas", que viviam nas ruas de Belém no fim do século XIX e início do XX, vendendo açaí, cheiro ${ }^{9}$, vasilhas de barro e flores, lavando roupas, costurando, trabalhando como criadas ou mesmo se prostituindo. Essas mulheres sofreram as mais diferentes formas de marginalização e discriminação, ao vivenciarem com maior liberdade o universo dos espaços públicos, atuando não apenas em serviços domésticos, mas também em atividades que lhes permitiam participar com mais recorrência do cotidiano público da cidade.

Nesse sentido, observamos que, mesmo que elas estejam simulando sua condição de trabalho no estúdio fotográfico, as mulheres escravizadas possuíam maior liberdade de atuação no espaço público, o que também colaborou para o estabelecimento de representações depreciativas delas mesmas, haja vista que, em oposição a essa imagem, as mulheres mais ricas eram estimuladas a frequentar as ruas apenas em determinadas ocasiões, quando iam ao teatros e às casas de chá, ou mesmo passeando pelas novas avenidas, e deveriam fazê-lo sempre acompanhadas (SOIHET, 2018).

Ainda a respeito de sua vestimenta, podemos observar que o tecido apresenta certa fluidez, e, pela posição social da mulher, é indicativo que o mesmo tenha sido de menor valor, pois, conforme aponta Drumond,

na maioria dos casos, as roupas destinadas aos escravos eram confeccionadas por eles mesmos, a partir da produção caseira de fios e tecidos grosseiros feitos de lã. Em outros, eram adquiridos nas lojas. 0 tecido mais utilizado para a vestimenta dos escravos era a linhagem. Tecido de linho da pior qualidade, era também utilizado para encapar fardos [...]. (DRUMOND, 2008, p.68)

Mesmo que essas imagens sejam registros de pessoas, temos que lembrar que essas representações se ajustaram aos interesses políticos do período em que elas foram produzidas.

\footnotetext{
Também chamado de cheiro-do-Pará, até hoje encontrado nos mercados públicos ou vendido nas ruas de Belém, resulta de uma combinação de raízes, cascas e paus aromáticos, ralados e misturados a trevos, jasmins e rosas, embrulhados em pedaços de papel. Os envelopes cheirosos são colocados em gavetas, baús e armários, perfumados as roupas. (FERNANDES, 2013, p.62)
} 
Tais retratos são bem mais que exemplares de documentação de indivíduos da realidade local, por vezes, nessas fotografias, o povo negro e mestiço apresenta olhares melancólicos, em posição de inferioridade e descalços, sem nenhuma referência a seus nomes ou de sua origem. Assim, esses elementos marcam a identidade que era imposta a eles, em que os fotógrafos auxiliavam no reforço e na reprodução do senso comum referente ao espaço desses indivíduos na sociedade.

\section{Considerações finais}

A fotografia é um dos meios mais eficazes para agrupar ideias e influenciar no comportamento, tanto que os fotógrafos da segunda metade do século XIX, estão vinculados não somente com as evoluções técnicas do processo fotográfico, mas também com os projetos implementados que vigoravam na época, pois em muitos casos, a fotografia era o suporte escolhido para realizar as propagandas oficiais do governo e, assim, inserir determinada sociedade nos moldes da "civilização".

Ainda que as mulheres dos retratos analisados estivessem à margem do processo de "modernidade" ambicionado pelo governo, suas imagens configuram a necessidade de autorrepresentação e de apelo ao consumo de "bens exóticos".

Beltramim (2009) também concede outra possibilidade interpretativa para a atuação dessas mulheres, e de escravizados em geral, nas fotografias, podendo ser mais uma forma de remuneração: “[...] era uma possibilidade de 'atuarem' como modelos para, em troca, obterem algum ganho para eles próprios, ou talvez, para aumentar a renda no dia de trabalho para seu senhor, se escravos fossem". (BELTRAMIM, 2009, p. 63)

Nas fotografias analisadas, encontramos diversos pontos em comum: a escolha de um fundo neutro, retratos de corpo inteiro, a predominância de eixos verticais na composição fotográfica, enquadramentos centralizados e com destaque, em primeiro plano, da mulher fotografada, bem como a adaptação de cenas urbanas dentro do estúdio.

No que concerne às vestimentas e aos adornos por elas utilizados, também devemos ressaltar que esses elementos compositivos poderiam ser "emprestados" somente para o momento da fotografia, pois, de acordo com Beltramim (2009), a imagem dos negros também servia como exibição da posição social dos senhores.

Também é válido ressaltar que a preocupação com a aparência esteve presente em todas as camadas socias do período, portanto, diferenciar-se, em um primeiro momento, era de fundamental importância no espaço da vida pública: "E é isso que acrescenta o componente identitário entre quem veste e quem vê. 0 universo material no qual cada grupo de pessoas está envolvido identifica-os perante a sociedade" (Drumond, 2008, p.132).

Outro ponto comum presente nos retratos das modelos registradas por Felipe Fidanza é a ausência do riso, que pode ser interpretada como uma situação desconfortante ou ainda como um sentimento de tristeza, tão comum na sociedade escravista. Também configura, segundo Beltramim, na 
como valor maior de uma temporalidade, refletido nas artes e na estética, na moral e na religião. [...] Para o século XIX, austeridade, postura contraída, contenção, seriedade, são valores gerais inscritos no corpo e no homem dos Oitocentos. (BELTRAMIM, 2009, p.68)

No Brasil dos séculos XVIII e XIX, os tecidos utilizados pelas damas funcionavam como marco de discriminação social: para as ricas, cabiam os serafins, as sedas e os veludos; e para a população comum, os tecidos inferiores, como o algodão, e, ao que tudo indica, as mulheres fotografadas por Fidanza, trajavam roupas confeccionadas com esse material.

Outra semelhança nessas fotografias são as flores presentes nos cabelos das mulheres, a fim de exercer o papel sinestésico de apelo visual e sensorial causado pelo perfume. Tal hábito foi relatado por alguns viajantes que passaram pela cidade de Belém, e que ainda permanecia no século XX, como fora documentado por João Affonso (1976). E, também, a presença de uma cruz pendendo no pescoço da "Cafusa" e da "Mulata", retratadas por Fidanza.

Conforme assinala Affonso (1976), a "Mulata Paraense" já estava deixando de circular nas ruas da capital no fim do século XIX. Uma de suas últimas representações teria sido a de David 0. Widhopff, no caderno ilustrado do jornal "A Província do Pará" de 1895, desenho que João Affonso inseriu ao lado do seu próprio registro, em 1916.

Affonso já apontava a morte simbólica da "Mulata Paraense": "Hoje, esse tipo desapareceu inteiramente do movimento da vida contemporânea de Belém", e, por esse motivo, "o presente estudo da indumentária de três séculos, em vez de acabar na atualidade, encerra-se com uma recordação do passado" (AFFONSO, 1976, p. 224), o que concedeu um arrojado desfecho para a sua obra ao lançar o olhar para a figura dessa mulher que, aos poucos, ia desaparecendo da cidade, mas que já fazia parte do imaginário popular, tanto que essa figura tornou-se sinônimo da típica mulher paraense, ainda que folclorizada.

Figueiredo (2012) aponta a cuidadosa descrição de João Affonso sobre o "tipo popular", que era a denominação que os folcloristas da época concediam às mulheres reconhecidas em qualquer parte da cidade, aspecto este que atribuía autenticidade à figura descrita, como símbolo de um tempo passado. 0 autor também assinala que a crioula da terra era a ponte entre o passado africano e a mestiçagem nacional e, por isso mesmo, era representada por João Affonso já perfeitamente aclimatada ao ambiente da casa brasileira.

A representação emblemática dessa personagem, a qual ainda está presente no imaginário da população local, ganhou uma nova configuração no traje típico das dançarinas de carimbó ${ }^{10}$ (figura 8): as saias das mulheres são coloridas, volumosas e rodadas, para garantir um efeito mais interessante ao serem movimentadas durante a dança. As blusas são de uma única cor, geralmente são batas brancas, e, por vezes, recebem aplicação de rendas.

\footnotetext{
10 carimbó é uma dança de roda típica do Estado do Pará, situado na região Norte do Brasil. A palavra "carimbó" é de origem indígena. Do tupi korimbó (pau que produz som) resulta da junção dos elementos curi, que significa "pau", e mbó, que significa "furado". 0 nome faz referência ao curimbó, principal instrumento musical utilizado nessa manifestação folclórica. 0 carimbó do Pará foi trazido ao Brasil pelos escravos africanos. Posteriormente, foram incorporadas influências indígenas e europeias, especialmente ibéricas. Disponível em: https://www.todamateria.com.br/carimbo/. Acesso em: 22 fev. 2019.
} 
FIGURA 8 - DANÇARINOS DE CARIMBÓ

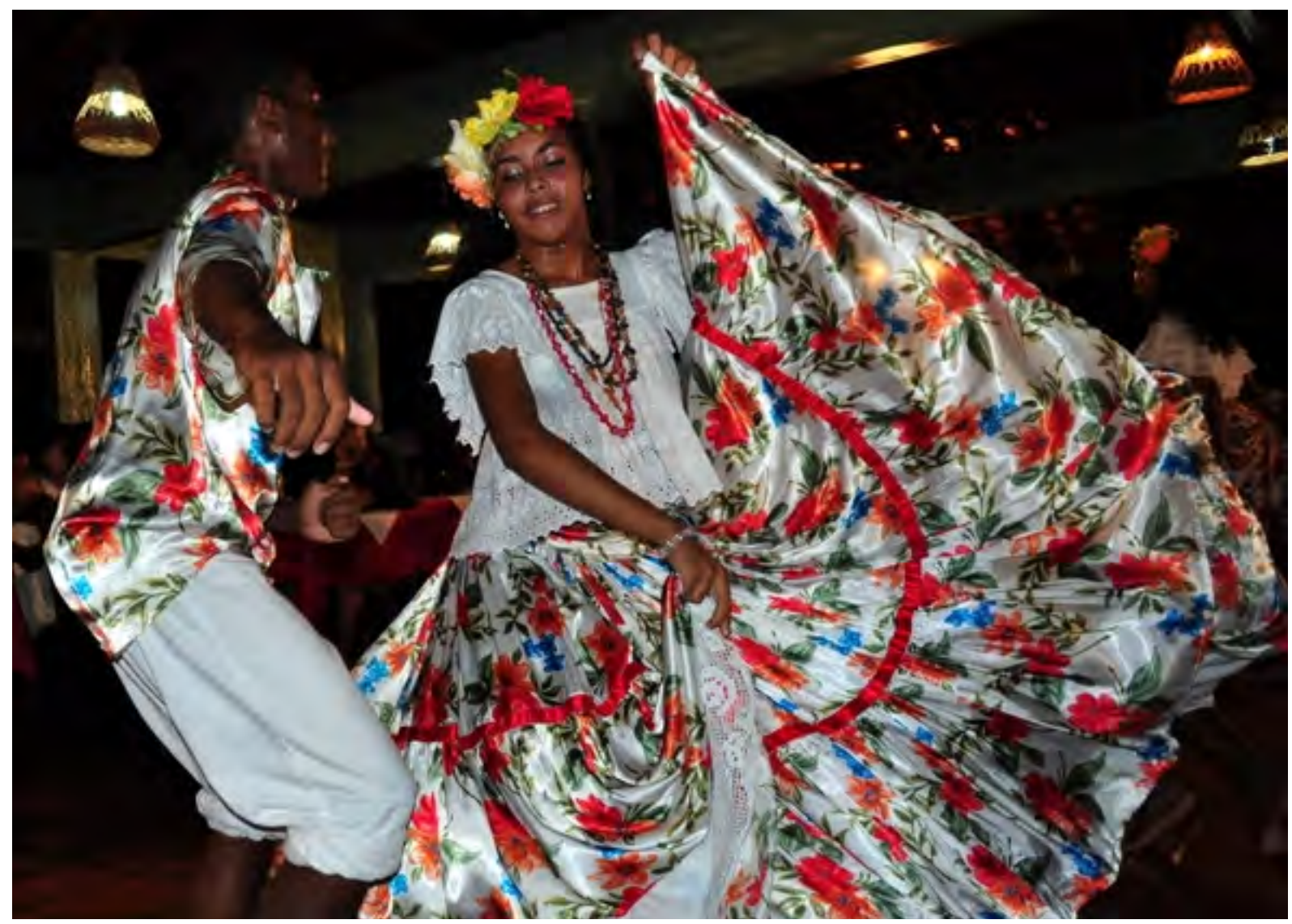

FONTE: HISTÓRIA DE MOTOCICLETA, 2011.

Disponível em: http://www.historiasdemotocicleta.com.br/galeria.php?id=23. Acesso em: 20 fev. 2020. Imagem obtida mediante download de arquivo.

O uso da blusa branca com rendas, segundo Anaíza Vergolino (citado por PAES, 2016), consiste em um elemento de permanência nos cultos das religiões de matriz africana no Pará, pois a indumentária marcada por esse tipo de blusa já era utilizada desde a época do batuque paraense, e ainda permanece nos dias atuais como elemento litúrgico dos cultos.

As dançarinas não usam sapatos ou sandálias e utilizam adornos no pescoço e nos pulsos, além de enfeitarem os cabelos com flores, configurando um jogo sinestésico de exibir-se e perfumar-se. Elas também vestem batas na cor branca, prática que nos remete às mulheres fotografadas por Fidanza, analisadas anteriormente. A maior diferença entre as roupas das dançarinas de carimbó e as das mulheres registradas pelas lentes de Felipe Fidanza está na saia. Enquanto a saia das dançarinas geralmente é confeccionada com tecidos floridos que podem receber aplicações de rendas e/ou folhos, as saias das mulheres analisadas nos registros ao longo do artigo são em cores claras ou brancas, por serem mais acessíveis. Assim, a construção da imagem das mulheres escravizadas na cidade de Belém perpassa pelo exotismo que, aliado aos modos de se vestir e se adornar, configura uma representação emblemática dessa personagem, ainda presente no imaginário da população local. 


\section{Referências}

AFFONSO, João. Três séculos de modas. Belém: Conselho Estadual de Cultura, 1976.

BARNARD, Malcolm. Moda e comunicação. Rio de Janeiro: Rocco, 2003.

BELTRAMIM, Fabiana. Sujeitos iluminados: a reconstituição das experiências vividas no estúdio de Christiano Jr. 270f. Dissertação (Mestrado em História) -Pontifícia Universidade Católica de São Paulo, São Paulo, 2009.

BURKE, Peter. Testemunha ocular: história e imagem. São Paulo: Edusc, 2004.

CACCAVONI, Arthur. Álbum descritivo Annuario dello stato del Pará. Gênova: F. Armanino, 1898.

CANCELA, Cristina Donza. Adoráveis e dissimuladas: as relações amorosas das mulheres das camadas populares na Belém do final do século XIX e início do XX. 1997.174f. Dissertação (Mestrado em Antropologia) - Universidade Estatual de Campinas, Campinas, 1997.

CARVALHO, Vânia Carneiro de. Gênero e artefato. 0 sistema doméstico na perspectiva da cultura material. São Paulo: Edusp/Fapesp, 2008.

CARVALHO, Vânia Carneiro de; LIMA, Solange Ferraz de. Usos sociais e historiográficos. In: LUCA, Tania Regina de; PINSKY, Carla Bassanezi. 0 historiador e suas fontes. São Paulo: Contexto. 2017, p.29-60.

DAMATTA, Roberto. Relativizando: uma introdução à Antropologia Social. Rio de Janeiro: Rocco, 2010.

DRUMOND, Marco Aurélio. Indumentária e cultura material: produção, comércio e usos da Comarca do Rio das Velhas (1711-1750). 2008. 217f. Dissertação (Mestrado em História) - Universidade Federal de Minas Gerais, Belo Horizonte, 2008.

EDWARDS, William Henry. A voyage up the river amazon including a residence at Pará. London: John Murray, 1847. Disponível em: https://www.biodiversitylibrary.org/ item/119342\#page/196/mode/2up. Acesso em: 20 jan. 2020.

FERNANDES, Caroline. 0 moderno em aberto: o mundo das artes em Belém do Pará e a pintura de Antonieta Feio. Belém: IAP, 2003.

FIGUEIREDO, Aldrin. Vestir a história: pintura, moda e identidade nacional da Amazônia, c. 1916-1923. Histórica - Revista Eletrônica do Arquivo Público do Estado de São Paulo, São Paulo, n.53, p. 1-13, abr. 2012. Disponível em: http://www.historica.arquivoestado. sp.gov.br/materias/anteriores/edicao53/materia01/. Acesso em: 20 jan. 2020. 
HIRSZMAN, Maria Lafayette Aureliano. Entre o tipo e o sujeito: os retratos de escravos de Christiano Jr. 2011. 215f. Dissertação (Mestrado em Artes) - Universidade de São Paulo, São Paulo, 2011.

IMADA, Heloísa Leite. Moda: desfile literário. Campinas: Unicamp /IEL/Setor de Publicações, 2019.

KOSSOY, Boris; CARNEIRO, Maria Luiza Tucci. 0 olhar europeu. São Paulo: Edusp, 2002.

KOUTSOUKOS, Sandra Sofia Machado. Negros no estúdio do fotógrafo. Campinas: Editora da Unicamp, 2010.

LEITE, Marcelo Eduardo. Typos de pretos: escravos na fotografia de Christiano Jr. Visualidades, Goiânia, v.9, n.1, p. 25-47, jan/jun. 2011. Disponível em: https://www. revistas.ufg.br/VISUAL/article/view/18368. Acesso em: 20 jan. 2020.

LIPOVETSKY, Gilles. 0 império do efêmero: a moda e seu destino nas sociedades modernas. São Paulo: Companhia das Letras, 1989.

MEGGS, Philip B.; PURVIS, Alston W. História do design gráfico. Trad.: Cid Knipel. São Paulo: Cosac Naify, 2009.

PAES, Francisco Augusto Lima. Vestígios do sagrado: a obra de arte como possibilidade de mediação entre religião e cultura na pintura de Antonieta Santos Feio. Revista Eletrônica Correlatio, São Paulo, v. 6, n.2, p.123-150, dez. 2016. Disponível em: https://www.metodista. br/revistas/revistas-ims/index.php/COR/article/view/7037. Acesso em: 20 jan. 2020.

PEREIRA, Rosa Cláudia Cerqueira. Paisagens urbanas: fotografias e modernidades na cidade de Belém (1846-1908). 2006. 190f. Dissertação (Mestrado em História Social da Amazônia) - Centro de Filosofia e Ciências Humanas, Universidade Federal do Pará, Belém, 2006.

PEREIRA, Rosa Cláudia Cerqueira; SARGES, Maria de Nazaré. Photografia Fidanza: um foco sobre Belém (XIX/XX). Revista Estudos Amazônicos, Belém, v. VI, n.2, p. 1-31, 2011. Disponível em: https://docplayer.com.br/14894667-Photografia-fidanza-um-foco-sobrebelem-xix-xx.html. Acesso em: 20 jan. 2020.

SANTOS, Irina Aragão dos. Tramas de afeto e saudade: uma biografia dos objetos e práticas vitorianas no Brasil oitocentista. Anais do 8o Colóquio de Moda. Rio de Janeiro. 2012. Disponível em: http://www.coloquiomoda.com.br/anais/Coloquio\%20de\%20Moda\%20 \%202012/GT06/ARTIGO-DE-GT/103402_Tramas_de_afeto_e_saudade.pdf. Acesso em: 20 jan. 2020. 
SARGES, Maria de Nazaré. Belém: riquezas produzindo a belle-époque (1870-1912). Belém: Paka-Tatu, 2002.

SCHMITT, Juliana. Vestuário e comportamento de luto no Brasil oitocentista. Anais do 13\% Colóquio de Moda. Bauru. 2017. Disponível em: http://www.coloquiomoda.com. br/anais/Coloquio\%20de\%20Moda\%20-\%202017/GT/gt_04/gt_4_VESTUARIO_E_ COMPORTAMENTO_DE_LUTO.pdf. Acesso em: 20 jan. 2020.

SOIHET, Rachel. Mulheres pobres e violência no Brasil urbano In: DEL PRIORE, Mary. História das mulheres no Brasil. 10. ed. São Paulo: Contexto, 2018, p. 362-400.

SOUZA, Gilda de Melo e. 0 espírito das roupas: a moda no século dezenove. São Paulo: Companhia das Letras, 1987. 